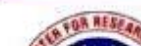 \\ (1) scceosoosen PUBLISHING \\ Sustainable Solutions \\ Review of Applied Management and Social Sciences \\ Journal homepage: http://ramss.sperd.org \\ ISSN (Print): 2708-2024 \\ ISSN (Online): 2708-3640
}

\section{Perceptions about Job Recruitment and Job Placement of Teachers Having B. Ed (Hons) Qualification}

\author{
Shehar Bano ${ }^{a}$, Hameed Nawaz ${ }^{b}$, Kishwer Naheed Rana ${ }^{c}$ \\ ${ }^{\text {a }}$ PhD Scholar of Education, University of Lahore, Pakistan \\ ${ }^{\mathrm{b}}$ Associate Professor, University of Lahore, Lahore, Pakistan \\ ${ }^{\mathrm{c}}$ Chairperson BISE, DG Khan, Pakistan
}

\begin{tabular}{|c|c|}
\hline ARTICLE DETAILS & \multirow{7}{*}{$\begin{array}{l}\text { ABSTRACT } \\
\text { The excellence in teaching and learning in academia depends on } \\
\text { teachers' abilities and process of recruitment. The current study } \\
\text { planned to investigate teachers' perceptions about job recruitment } \\
\text { and job placement of B. Ed (hons) qualified teachers. The } \\
\text { objectives were to explore teachers' perceptions about job } \\
\text { placement and job recruitment and to explore the distinction in } \\
\text { male and female teachers' opinions about the job placement and } \\
\text { job recruitment. The sample comprised of } 50 \text { teachers who had B. } \\
\text { Ed. (Hons) qualification and now working in education } \\
\text { department. The self-developed instrument, Job Placement and } \\
\text { Recruitment Survey was used. The data were analyzed using } \\
\text { SPSS. Frequency analysis and t-test were applied. The results } \\
\text { revealed that most teachers were willing and claimed that they } \\
\text { sure that govt. has fair recruitment policy of teaching jobs. While } \\
40 \% \text { teachers denied that govt. has fair recruitment policy of } \\
\text { teaching jobs. About 61\% teachers told that they passed their } \\
\text { recruitment test while preparing their exams through the courses } \\
\text { they studied during training. } 72 \% \text { teachers perceived that subjects } \\
\text { they studied during training helped them during recruitment } \\
\text { exams. No difference was found between gender of teachers about } \\
\text { their job recruitment and job placement. }\end{array}$} \\
\hline & \\
\hline pted 16 Aug 2020 & \\
\hline Available Online 30 Sep 2020 & \\
\hline $\begin{array}{l}\text { Keywords: } \\
\text { Job placemer } \\
\text { Teachers' cor }\end{array}$ & \\
\hline & \\
\hline DO & \\
\hline
\end{tabular}

(C) 2020 The authors. Published by SPCRD Global Publishing. This is an open access article under the Creative Commons Attribution-

NonCommercial 4.0

Corresponding author's email address asif.iqbal@ue.edu.pk

\section{Introduction}

The excellence in teaching and learning in academia depends on teachers' abilities and the fair process of recruitment and job placement. The teaching job demands a combination of judgmental expert and proficient use of evidence based competence in teaching (Iqbal, 
Hussain,Mushtaq, \&Javaid, 2019). The competent teachers produce outstanding results in teaching. The decline of students' achievement is credited to the poor job recruitment, under estimated job placement and deteriorating quality in education system.Majority of candidates undergo unemploymentbecause as they have no right job to do. The process of teachers'selection, recruitment, and placement is affected to a great extent because experienced and skilled teachers are not inducted to job (Osaretin, 2012).

The mainobjective of recruitment process is to encourage and attract moreapplicants to apply in teaching. It develops a talented pool of applicants to make selection the best applicants for the profession. It containspriorities offuture and present needs of organizations with best job analysis accomplishments (Mascarenhas, 2011).

Many factors are responsible for secreted criteria for instructors'selection and recruitment. They are gender, religious affiliation, age, and physical aspirations. The teachers ingovt. schools have low satisfaction in current social norms in teaching profession and feel themselves asmis-utilizing potentials (Abdou, 2012).

The teaching profession has a prestigious one and teachers should select on well-defined and clear cut criteria. The department should invite diversified caliber holder candidates. The value should be given on academic qualification rather than to select on favoritism basis (Kelkay, 2018).The recruitment is the first phase of selection. Selectioninvolves pickingcapable and trained applicants suitable for the position (Oxford University Press, 2012). Outstandingselection measures are vital for locatingbest workforcein competitive pool. The training and employees'developmentis critical; it is hard to overcome poor qualified employees.According to Tripathy and Reddy(20o9a), the basic source of the organizations are their human resources. There is a need to retain talented, creative, and devoted teachers in the profession. This containsa long term planning, selection and recruitment for organizations. The attainmentof teachers' development and skillsviarefinedselection and recruitment has positive influence on efficiency and effectiveness. According to John(2015), selection and recruitment activities hasincorporated keyrole for organization.The studies of MargaretandCaroline(2009)revealed that selection and recruitment procedures enable the choice of applicants.

\section{Teacher Recruitment and Candidates' Job Choices}

One strand of research on educator employing has concentrated on seeing how enlistment messages impact candidates' view of employments and their attraction. As Young, Levin, and Wallin(2006) revealed that tests what they get engaging about a line of work or work setting. The commonsense objective of this examination is to create information that can help schools and locale make their enlistment messages progressively compelling in pulling in candidates and persuading possibility to acknowledge bids for employment.

\section{Review of Related Literature}

\subsection{Job Placement of Teachers}

\subsubsection{The Challenge in Teacher s' Demand and Supply}

Training experts in many nations are confronting different difficulties as for the instructing calling. Numerous nations have genuine deficiencies of staff. Now and again, these are connected to explicit subjects or certain land regions, while in others they are all the more for the most part because of the maturing educator quantity and attrition rates from the calling. Oversupply is 
additionally an issue in certain nations or in certain regions and subjects. Moreover, low enrolment is the issue and poor teachers' qualities in teaching profession add the difficulties in teaching work. While observing these improvements is positively an initial phase in understanding the developments occurring specifically in training of teachers at all levels.

\subsubsection{Challenges in Teacher Supply And Demand}

It is fascinating to see that many training frameworks face comparative difficulties concerning teachers' flexibly and demand, regardless of whether they have completedtheir degrees or not. Many nations have severe shortage of teaching staff.This is usually due to lack of interest in teaching profession and high attrition rates from the profession. Therefore, very minute may be discovered in quality of teacher education, without planning proper selection and recruitment of teachers (Buchberger\& Byrne, 1995; Koster et al., 2005;Korthagen, 2000). This is by all accounts the case for a few nations which demonstrate oversupply as their fundamental demands. Many nations are arranging the balance between demands and supply of teachersas significant investigation for improving teaching qualityin teaching profession.

\subsubsection{Unemployment Rates in Teaching Job and Teachers' Professional Standards}

With consistent increments in the teacher excess, the joblessness ratewas $3 \%$ in 2006 and swift up to $38 \%$ in 2013 . After four years, the unemployment rate has fallen significantly to $14 \%$.The improvement in teachers' professional standards were criticized over date as perceived by many researches. The main criticism was in the process of developing the standards (Zuzovsky \& Libman, 2003).The Ontario graduate teachers currently believe themselves as completely employed. In spite of better job rates for Ontarioteachers' education for past years, considerable difference persists among Ontario-resident teachers liable to language and qualification (Transition to Teaching, 2017). In spite of the improved activity rates for Ontario educator training graduates as a rule in the course of recent years, significant differences persevere among Ontario-occupant instructors relying upon language and divisional capabilities (McIntyre, 2003).

The less currently plan to teach outside the area in the following year four alumni from English language programs authorized in 2016 applied to Ontario tuition based schools. Around one of every seven recently authorized alumni recruited in Ontario for the 2016-17 school year instructed at tuition based schools. Most of first-year teachers' work in occupations that don't require Ontario teacher accreditation. Many pursue the work with kids and youth, mentoring, youth training, after school programming or different employments identified with instruction.

The training work showcase differs over the area, with detailed first-year joblessness most elevated in Toronto and focal Ontario and least in eastern Ontario. The reinforcing educator work advertise this year brought about further gains for recently Ontario-authorized instructors taught outside the area. Ontarians instructed while living abroad, the individuals who finished their educator training at US fringe schools, new Canadian instructors and instructors who relocated to Ontario following educator training in other Canadian regions all detailed higher paces of full work in the first year in the wake of authorizing, as did Ontario college graduates. Most of first-year educators who are alumni of Ontario college instructor training programs rate their work on instructing and course work profoundly. They recognize a scope of primary expert information and instructive abilities for which they were not also arranged or potentially which are high on their need records for future expert turn of events (McIntyre, 2003). 


\subsection{Less Facilities in Teaching Jobs}

There are many reservations in teaching job. The teachers are said to have least economic status in the society. They are contented one to arrange their life facilities. No other incentives are provided to teachers so for. Now a day, teachers have most busy schedule as they have to fulfil all the duties from students to all stakeholders. Many schools are lack of basic physical facilities like boundary walls, clean water and furniture. Teacher are assigned the divine duties to transmit the knowledge to students. Their work is purposeful and too much curious (Karim, Lodhi, \& Usman, 2011). The Transition to teaching review Ontario platform interest and joblessness rates for firstthrough fifth-year teachers, along with College data improving teaching profession (McIntyre, 2003).

\subsection{Teaching Profession and Teacher Mobility}

The change from initial teacher training to proficient professional has emerged from teachers' point of view point of view. The European Commission underlines that improving educators' choice and enrollment procedures may help in distinguishing the most appropriate competitors. The conventional method to recruit instructors in Europe by acquiring suitable personal. The method by which instructors are chosen and enrolled may have an effect on the nature of the encouraging workforce in teaching profession.

\subsection{Recruiting fully Qualified Teachers}

There are three primary frameworks in Europe for selecting completely qualified teachers for their first appointment, open enrollment, serious assessment and applicants' records. Under open recruitment, the procedure is normally overseen by schools, some of the time related to the neighborhood authority. The open enrollment process infers the nonappearance of a top-level framework for supply teachers to schools: the vacant teaching positions are filled by competent applicants applying for work on school basis. Many training frameworks of the entire method can be exceptionally managed, while in others just the fundamental approaches are controlled.

\subsection{Objectives of the Study}

The objectives were:

- To explore teachers' perceptions about their job placement and job recruitment?

- What is the distinction in male and female teachers' opinions about the job placement?

- What is the distinction in male and female teachers' opinions about the job recruitment?

\subsection{Research Questions}

The research questions to achieve objectives of study were:

1. What are teachers' perceptions about their job placement?

2. What are teachers' perceptions about their job recruitment?

3. What is the distinction in male and female teachers' opinions about the job placement?

4. What is the distinction in male and female teachers' opinions about the job recruitment?

\section{Research Design}

It was case study. Only Department of Education from GC University Fsd. Was selected.

\subsection{Population}

There were total of 50 teachers participated in the study. Among them, thirty-one (64\%) were male teachers and eighteen (36\%) were female teachers. Thirty-six teachers (73\%) who have experience up to three years. The teachers with more than three years of experience were fourteen 
(27\%). Therefore, most of the teachers have above three years of teaching experience.

\subsection{Sample of the Study}

Fifty teachers with B. Ed. (Hons) appointed in secondary schools participated in the study. Census sampling technique was used. As most appropriate techniques of a study of every subject in a population. All the teachers with B. Ed. (Hons) qualification were selected from district Faisalabad. The teachers were categorized in Tehsil, gender, area wise.

\subsection{Instrument of the Study}

The self-developed instrument, Job Placement, Content Competencies and Professional Attitude Survey (JPCCPAS). It was adapted from studies of Long, Ibrahim, \& Kowang, 2014; Norazman, Nor'ain, \& NurFazliana, 2012; and Ramsden, 1991. Only teachers' job placement and job recruitment items were selected, revised and analyzed. In addition, professional attitude indicators were also included.

\subsection{Data Analysis}

The data were analyzed for answering the research questions. For investigating the difference between the job recruitment and job placement with respect to gender, t-test was applied. For analyzing the teachers' perceptions about the indicators, frequency analysis was used.

RQ: 1 . What are teachers' perceptions about their job placement?

Table 1: Frequency Analysis of Job Placement of Teachers

\begin{tabular}{|l|l|l|l|l|l|l|}
\hline S\# & Job Placement & $\begin{array}{l}\text { SDA } \\
\mathbf{\%}\end{array}$ & $\begin{array}{l}\text { DA } \\
\mathbf{\%}\end{array}$ & $\begin{array}{l}\text { U } \\
\mathbf{\%}\end{array}$ & $\begin{array}{l}\mathbf{A} \\
\mathbf{\%}\end{array}$ & $\begin{array}{l}\text { SA } \\
\mathbf{\%}\end{array}$ \\
\hline $\mathbf{1}$ & $\begin{array}{l}\text { The teachers participate in work experience and in } \\
\text { workplace learning programs. }\end{array}$ & 6 & $\mathbf{2}$ & 50 & 40 \\
\hline 2 & $\begin{array}{l}\text { It is somewhat difficult to get a teaching job on the } \\
\text { basis of my degree. }\end{array}$ & 0 & 6 & 4 & 54 & 36 \\
\hline 3 & $\begin{array}{l}\text { There are more job opportunities in other fields } \\
\text { than teaching professions. }\end{array}$ & 6 & 16 & 12 & 36 & 30 \\
\hline 4 & $\begin{array}{l}\text { Being a teacher for me was the last choice I have } \\
\text { availed. }\end{array}$ & 34 & 28 & 10 & 16 & 16 \\
\hline
\end{tabular}

The table 1 revealed a frequency distribution about the job placement of the teachers. Forty percent teachers were strongly agreed and told that they participate in work experience and in workplace learning programs. Fifty percent teachers were agreed about participation in learning experiences. Two percent were undecided and two percent were disagreed about participation in learning. Thirty-six percent teachers were strongly agreed and fifty-four percent teachers were agreed that they found it difficult to get a teaching job on the basis of their degree. Four percent teachers were undecided and six percent teachers were disagreed to the statement that they found it difficult to get a teaching job on the basis of their degree. Thirty percent teachers were strongly agreed and thirty-six percent teachers agreed that there are more job opportunities in other fields than teaching professions. Twelve percent teachers were undecided about the opportunities of teaching job. Sixteen percent teachers were disagreed that are more job opportunities in other fields than teaching professions. Sixteen percent teachers were strongly agreed and sixteen percent 
teachers were agreed that being a teacher for them was the last choice they have availed. Ten percent were undecided about the statement. Twenty-eight percent teachers were disagreed and thirty-four percent teachers were strongly disagreed that being a teacher for then was the last choice they have availed.

RQ: 2. What are teachers' perceptions about their job recruitment?

Table 2: Frequency Analysis of Job Recruitment of Teachers

\begin{tabular}{|c|c|c|c|c|c|c|}
\hline S\# & Job Recruitment & $\begin{array}{l}\text { SDA } \\
\%\end{array}$ & $\begin{array}{l}\text { DA } \\
\%\end{array}$ & $\begin{array}{l}\mathrm{U} \\
\%\end{array}$ & $\begin{array}{l}\text { A } \\
\%\end{array}$ & $\begin{array}{l}\text { SA } \\
\%\end{array}$ \\
\hline 5 & $\begin{array}{l}\text { I sure that govt. has fair recruitment policy of } \\
\text { teaching jobs. }\end{array}$ & 32 & 8 & 4 & 34 & 22 \\
\hline 6 & $\begin{array}{l}\text { I have full confident on my competencies that I } \\
\text { gained during my course work (Teacher training). }\end{array}$ & 4 & 4 & 0 & 42 & 50 \\
\hline 7 & $\begin{array}{l}\text { My professional competence made me to get } \\
\text { teaching job easily. }\end{array}$ & 2 & 20 & 2 & 34 & 42 \\
\hline 8 & I was selected purely on merit basis. & $\mathrm{O}$ & 4 & 4 & 20 & 72 \\
\hline 9 & $\begin{array}{l}\text { The big hurdles in seeking my job are the } \\
\text { irrelevant teaching techniques I was force to study } \\
\text { during my professional training. }\end{array}$ & 10 & 30 & 20 & 30 & 10 \\
\hline 10 & $\begin{array}{l}\text { I passed my recruitment test while preparing my } \\
\text { exams through the courses I studies during } \\
\text { training. }\end{array}$ & 8 & 22 & 10 & 48 & 13 \\
\hline 11 & $\begin{array}{l}\text { The subjects I studied during training did not help } \\
\text { me during recruitment exams. }\end{array}$ & 34 & 38 & 4 & 20 & 4 \\
\hline
\end{tabular}

In table 2, the frequency method was analyzed to explore perceptions of teachers about job recruitment. The majority of teachers (56\%) were agreed and strongly agreed and claimed that they sure that govt. has fair recruitment policy of teaching jobs. While $40 \%$ teachers denied that govt. has fair recruitment policy of teaching jobs. Most of the teachers 92\% told that they were agreed and strongly agreed about confident on their competencies that they gained during their course work (Teacher training). About $76 \%$ teachers opined that professional competence made them to get teaching job easily. 92\% teachers claimed that they were selected purely on merit basis. There were equal perceptions of teachers $(40 \%)$ and claimed that big hurdles in seeking their job were the irrelevant teaching techniques they forced to study during their professional training. About $61 \%$ teachers told that they passed their recruitment test while preparing their exams through the courses they studied during training. $72 \%$ teachers perceived that subjects they studied during training helped them during recruitment exams. It was a negative statement and cross question with regard to pervious question.

RQ: 3. What is the distinction in male and female teachers' opinions about the job placement? 
Table 3: Comparison of Opinions of Male and Female Teachers about the Job Placement

\begin{tabular}{|l|l|l|l|l|l|l|}
\hline \multirow{2}{*}{ Indicator } & Gender & $\mathbf{N}$ & Mean & Std. D. & t-value & $\mathbf{p}$ \\
\hline Job Placement & Male & 32 & 3.6016 & .69809 & \multirow{2}{*}{.091} & .928 \\
\cline { 2 - 7 } & Female & 18 & 3.5833 & .65305 & & .928 \\
\hline
\end{tabular}

According to table 3, the t-test about to comparing teachers' opinions in the job placement was applied. It shows that there is a non-significant difference was found between gender of teachers about their job placement. It is obvious that both groups have same perceptions. The mean achievement score of males $(M=3.6016, s d=.69809)$ and females $(M=3.5833, s d=.65305), t(48)$ $=.091$ teacherson the indicator of job placement. So, the research question about to comparing teachers' opinions in the job placement answered in negative.

RQ: 4. What is the distinction in male and female teachers' opinions about the job recruitment?

Table 4: Comparison of Opinions of Male and Female Teachers about the Job Recruitment

\begin{tabular}{|l|l|l|l|l|l|l|}
\hline Indicator & Gender & $\mathbf{N}$ & Mean & Std. D. & t-value & $\mathbf{p}$ \\
\hline $\begin{array}{l}\text { Job } \\
\text { Recruitment }\end{array}$ & Male & 32 & 3.5417 & .62504 & \multirow{2}{*}{.719} & .476 \\
\cline { 2 - 7 } & Female & 18 & 3.4259 & .36255 & & \\
\hline
\end{tabular}

In table 4 , the t-test was used to comparing teachers' opinions in the job recruitment was applied. It shows that there is a non-significant difference was found between gender of teachers about their job recruitment. It is clear that both groups had same opinions. The mean achievement score of males $(M=3.5417, s d=.62504)$ and females $(M=3.4259$, $s d=.36255), t(48)=.719$ teacherson the indicator of job recruitment. So, the question about to comparing teachers' opinions in the job answered in negative.

\section{Results and Discussion}

Majority of teachers were agreed about participation in learning experiences. Majority of teachers were strongly agreed and fifty-four percent teachers were agreed that they found it difficult to get a teaching job on the basis of their degree. Thirty percent teachers were strongly agreed and thirty-six percent teachers agreed that there are more job opportunities in other fields than teaching professions. Sixteen percent teachers were strongly agreed and sixteen percent teachers were agreed that being a teacher for them was the last choice they have availed. Twenty-eight percent teachers were disagreed and thirty-four percent teachers were strongly disagreed that being a teacher for then was the last choice they have availed.

The majority of teachers (56\%) were agreed and strongly agreed and claimed that they sure that govt. has fair recruitment policy of teaching jobs. While $40 \%$ teachers denied that govt. has fair recruitment policy of teaching jobs. Most of the teachers 92\% told that they were agreed and strongly agreed about confident on their competencies that they gained during their course work (Teacher training). About 76\% teachers opined that professional competence made them to get teaching job easily. Ninety-two teachers claimed that they were selected purely on merit basis. There were equal perceptions of teachers (40\%) and claimed that big hurdles in seeking their job were the 
irrelevant teaching techniques they forced to study during their professional training. About $61 \%$ teachers told that they passed their recruitment test while preparing their exams through the courses they studied during training. $72 \%$ teachers perceived that subjects they studied during training helped them during recruitment exams. It was a negative statement and cross question with regard to pervious question.

A non-significant difference was found between gender of teachers about their job placement. It is obvious that both groups have same perceptions. As the recruitment policy is a matter of govt. There is same process both male and female teachers experience at their job. It shows that there is a non-significant difference was found between gender of teachers about their job recruitment. It is clear that both groups had same opinions. The job recruitment is the same for both male and female teachers.

\section{References}

Abdou, A. A. (2012). Teachers' Recruitment and Selection Practices within Different Schooling Systems in Egypt.Unpublished Masters Theses, The American University in Cairo School of Graduate Education.

Buchberger, F., \& Byrne, K. (1995). Quality in teacher education a suppressed theme?European Journal of Teacher Education, 18(1), 9-23.

John, S. (2015). Organization and management. New Delhi: Tata McGraw-Hill publishing Company limited.

Kalkey, A. D. (2018). Practice and challenges of recruitment and selection of teachers in private primary school ofBahir Dar City, Ethiopia.American Journal of Educational Science, 4(4),159-167.

Karim, R. A., Lodhi, F. A., \& Usman, M. (2011). Facilities of Government \&private secondary school teachers of Karachi, Pakistan: A comparative analysis. International Journal of Academic Research in Business and Social Sciences, 1(s), 193-202.

Korthagen, F. A. J. (2004). In search of the essence of a good teacher towards a moreholistic approach in teacher education. Teaching and Teacher Education, 20(1),77-97.

Koster, B., Brekelmans, M., Korthagen, F. A. J., \&Wubbels, T. (2005). Qualityrequirements for teacher educators. Teaching and Teacher Education, 21(2), 157-176.

Korthagen, F. A. J. (2000). Teacher educators: From neglected group to spearhead in thedevelopment of education. In G. M. Willems, J. H. J. Stakenborg, \& W. Veuglers(Eds.), Trends in Dutch teacher education (pp. 35-48). Leuven: Garant.

Long, C. S., Ibrahim, Z., \& Kowang, T. O. (2014). An Analysis on the Relationship between Lecturers' Competencies and Students' Satisfaction. International Education Studies, 7(1), 36-46.

Margaret, F., \& Caroline, H. (2009). Introducing human resource management (4th ed.). London: Pearson Education Limited.

Mascarenhas, M. (2011).Issues in recruitment and selection. International Journal of Research in Commerce \& Management, 2(8), 125-131.

McIntyre, F. (2003). Transition to teaching: New teachers of 2001 and 2002. Report oftheir first two years of teaching in Ontario. Toronto, ON: Ontario College ofTeachers.

Norazman, A., Norain, M. T., \& NurFazliana, R. (2012). The quality of teaching and learning of mathematic teachers. Discovering Mathematics, 34(1), 105-112.

Osaretin, E. F. (2012). Recruitment, selection \& placement of teaching staff in institutions of learning with reference to higher education. A project submitted to Milton Keynes Language Centre in partial fulfilment of the requirement for the award of Diploma in Teaching in the Lifelong Learning Sector.

Oxford University Press. (2012). Human resource management: Ethics and employment, Oxford University Press Inc., New York.

Ramsden, P. (2006). A performance indicator of teaching quality in higher education: The Course Experience Questionnaire. Studies in Higher Education, 16(2), Retrieved on 14 July 2020 from 
https://doi.org/10.1080/0307507911233138294

Tripathy, P., \& Reddy, H. (2009a). Principles of management. (2nd ed.). New Delhi: Tata M GrawHill publishing Company Limited.

Young, L., Levin, B., \&Wallin, D. (2006). Understanding Canadian schools: An Introduction to Educational Administration (4th ed.). Scarborough, ON: Nelson. 